\title{
Purification and Characterization of NADP Specific Isocitrate Dehydrogenase from Ammonia-oxidizing Chemoautotrophic Nitrosomonas europaea ATCC 25978
}

\author{
ReiJi Takahashi, Tomoyoshi Kayo, Takashi OHmori \\ and Tatsuaki Tokuyama* \\ Department of Agricultural Chemistry, College of Agriculture and Veterinary Medicine, \\ Nihon University Setagaya, Tokyo 154, Japan
}

(Received October 22, 1991 - Accepted November 30, 1991)

\begin{abstract}
Ammonia-oxidizing chemoautotrophic Nitrosomonas europaea exhibited the NADP-specific isocitrate dehydrogenase (ICDH) activity. Isocitrate-oxidizing activity was found in two fractions (ICDH-FI and ICDH-FII) on a DEAE-Sepharose CL-6B. These enzyme proteins with isocitrateoxidizing activity were further purified as electrophoretic homogeneity using gel filtration (Cellulofine GCL-2000- $\mathrm{m}$ ) and then ion exchange chromatography (Mono Q). These enzymes were purified about 69-fold for ICDH-FI and about 140-fold for ICDH-FII. The molecular weights were determined as both 82,000 for both, using gel filtration and SDS-PAGE of enzymes. The isoelectric points of ICDH-FI and ICDH-FII were $\mathrm{pH} 5.8$ and 6.2, respectively.

The $\mathrm{pH}$ and temperature optima for ICDH-FI and ICDH-FII were $\mathrm{pH} 8.5$ and 8.0 , respectively, and about $55^{\circ} \mathrm{C}$ for both enzymes. The enzymes were stable up to $45^{\circ} \mathrm{C}$ and acted specifically on $\mathrm{D}$ or DL-isocitrate and not on any other organic acids tested. The apparent $K \mathrm{~m}$ values of ICDH-FI for D- and DL-isocitrate were $15.0 \mu \mathrm{M}$ and $17.5 \mu \mathrm{M}$, respectively and $K \mathrm{~m}$ values of ICDH-FII for Dand DL-isocitrate were $13.0 \mu \mathrm{M}$ and $11.5 \mu \mathrm{M}$, respectively. Both enzymes were strongly activated by $\mathrm{Mn}^{2+}$ and $\mathrm{Mg}^{2+}$, and inhibited by $\mathrm{Cu}^{2+}, \mathrm{Ni}^{2+}, \mathrm{Zn}^{2+}$ and $\mathrm{Hg}^{2+}$. They were strongly inhibited by $p$-chloromercuribenzoate.
\end{abstract}

Key words : Nitrosomonas europaea, ammonia-oxidizing bacteria, isocitrate dehydrogenase

\section{Introduction}

Nitrosomonas europaea is an obligate chemoautotrophic bacterium which oxidizes ammonium to nitrite via a pathway that includes hydroxylamine as an intermediate ${ }^{2)}$. Most studies on $N$. europaea have dealt with the ammonium oxidation pathway. However, little attention has been paid to the anabolism of bacterium.

NADP-specific isocitrate dehydrogenase [EC 1. 1.1.42] catalyzes the oxidative decarboxylation of

*Corresponding author isocitrate to 2-oxoglutarate in the presence of NADP and is commonly known as $\mathrm{ICDH}^{6)}$. Although heterotrophic bacterial ICDH has been extensively studied ${ }^{9,14,17)}$, no information is available about this enzyme in $N$. europaea and its possible role in the bacterium. We have previously demonstrated the effectiveness of isocitrate and 2-oxoglutarate on the growth of $N$. europaea, a representative chemoautotroph ${ }^{10)}$. We investigated the activity of dehydrogenases involved in the tricarboxyric acid cycle in cell-free extract from $N$. europaea. Results of the study showed the prominent metabolic activity of ICDH. This finding 
was consistent with the results obtained by Hooper on $N$. europaea ATCC 197187).

In this paper, we described the purification and some of the properties of NADP-specific ICDH from N. europaea ATCC 25978.

\section{Materials and Methods}

\section{Microorganisms and culture conditions}

Nitrosomonas europaea ATCC 25978 was used throughout this study ${ }^{19}$. The culture medium (P-medium) was composed of $\mathrm{Na}_{2} \mathrm{HPO}_{4}, 13.5 \mathrm{~g}$; $\mathrm{KH}_{2} \mathrm{PO}_{4}, 0.7 \mathrm{~g}$; $\left(\mathrm{NH}_{4}\right)_{2} \mathrm{SO}_{4}, 2.5 \mathrm{~g} ; \mathrm{MgSO}_{4} \cdot 7 \mathrm{H}_{2} \mathrm{O}$, $0.1 \mathrm{~g} ; \mathrm{NaHCO}_{3}, 0.5 \mathrm{~g} ; \mathrm{CaCl}_{2} \cdot 2 \mathrm{H}_{2} \mathrm{O}, 5 \mathrm{mg}$; chelated iron (Fe-EDTA, Dojindo Laboratories Co. Ltd., Japan), $0.1 \mathrm{mg}$ and deionized water, 1 liter $^{12)}$. The initial $\mathrm{pH}$ of the medium was $8.2 \pm 0.5$, it was not further adjusted. The stock culture was kept at $5^{\circ} \mathrm{C}$ after aerobic growth in the P-medium. The seed culture was prepared in a 3-liter Erlenmeyer flask containing 1 liter of the medium by rotary shaking of the culture $(200 \mathrm{rpm})$ for 7 days after inoculation of $100 \mathrm{ml}$ of the stock culture. The main culture was done in a 10 liter flat-bottom flask with an aeration apparatus containing 10 liters of the medium ${ }^{16}$.

All cultivation was performed at $29^{\circ} \mathrm{C}$. Cells from 110 liters of liquid culture prepared using the procedure described above were sedimented by continuous flow at $12,000 \times \mathrm{g}$ in a refrigerated centrifuge with a flow rate of 7 to 8 liters per hour at $5^{\circ} \mathrm{C}$.

\section{Assay for ICDH activity.}

The ICDH activity was assayed using the method of Cook et al. ${ }^{5}$. The rate of NADP reduction by isocitrate was measured by following the increase of absorbance at $340 \mathrm{~nm}$ using a Simadzu 160A spectrophotometer with a thermostated cell compartment at $40^{\circ} \mathrm{C}$. The standard reaction mixture contained, in a total volume of 3.0 $\mathrm{ml}, 0.5 \mathrm{mM} \mathrm{MnCl}_{2}, 0.15 \mathrm{mM}$ NADP, $0.17 \mathrm{mM}$ DL-(or D-) isocitrate, $20 \mathrm{mM}$ phosphate buffer, (pH 8.0, P-buffer) and enzyme.
One unit of the enzyme was defined as the amount producing one $\mu$ mole of the product per min. Specific activity was expressed as units per $\mathrm{mg}$ protein. The protein concentration was determined using a dye-binding assay method as described by Bradford ${ }^{3)}$, or by measuring the absorbance at $280 \mathrm{~nm}^{11)}$. The latter method was used for monitoring protein during column chromatography.

\section{Purification of ICDH}

Step 1: Preparation of cell-free extract. Cells ( $5.0 \mathrm{~g}$ wet wt.) of the bacteria from a $110 \mathrm{~L}$ culture were washed once with chilled P-buffer and resuspended in $20 \mathrm{ml}$ of same buffer. The cells were then disrupted by treatment with a French press under a pressure of approximately $500 \mathrm{~kg}$ / $\mathrm{cm}^{2}$. The homogenates were centrifuged at $12,000 \times \mathrm{g}$ for $30 \mathrm{~min}$ to remove unbroken cells and cell debris. The supernatant was centrifuged at $140,000 \times \mathrm{g}$ for $30 \mathrm{~min}$ and the resultant supernatant was used as the cell-free extract. All purification procedures were performed at $0-4^{\circ} \mathrm{C}$.

Step 2: Ammonium sulfate fractionation. Solid ammonium sulfate was added to the cell-free extract. The 40-60\% ammonium sulfate precipitate was collected by centrifugation $(9,500 \times \mathrm{g}, 10$ $\mathrm{min}$ ) and dissolved in a small volume of $10 \mathrm{mM}$ Tris-HCl buffer ( $\mathrm{pH}$ 7.5). The enzyme solution was dialyzed against the same buffer for overnight.

Step 3:DEAE-Sepharose CL-6B column chromatography. The dialyzed enzyme solution was applied on a DEAE-Sepharose CL-6B (Pharmacia Fine Chemicals, Sweden) column $(1.6 \times 30$ $\mathrm{cm})$ equilibrated with the $10 \mathrm{mM}$ Tris- $\mathrm{HCl}$ buffer (pH 7.5). After the column was washed with the same buffer, the elution was performed with a linear gradient of $\mathrm{NaCl}$ in the same buffer ( 0 to 0.7 M) at a flow rate of $12 \mathrm{ml} / \mathrm{h}$, and the elute was collected in 1-ml fractions. The active fractions were collected and dialyzed against the same buffer, overnight. The enzyme solution $(15 \mathrm{ml})$ 
was concentrated $2 \mathrm{ml}$ by osmotic ultracentrifugation using Ficoll 400 (Pharmacia).

Step 4: Gel filtration on a Cellulofine GCL2000- $m$ column. The concentrated enzyme solution was applied on a Cellulofine GCL-2000-m (Seikagaku kogyo Co. Ltd., Tokyo) column $(0.9 \times$ $60 \mathrm{~cm}$ ) equilibrated with P-buffer. The elution was done with the same buffer at a flow rate of 6 $\mathrm{ml} / \mathrm{h}$ and the enzyme fractions were pooled. The enzyme solution $(5 \mathrm{ml})$ was concentrated to $0.5 \mathrm{ml}$ by Ficoll 400 .

Step 5: Mono $Q$ column chromatography. The enzyme solution $(0.5 \mathrm{ml})$ was applied on to FPLC (Fast Protein Liquid Chromatography, Pharmacia) with a Mono Q column $(0.5 \times 5 \mathrm{~cm})$ buffered previously with P-buffer. The elution of the enzyme was performed by a linear gradient of $\mathrm{NaCl}(0$ to $0.1 \mathrm{M})$ in the same buffer. The active fractions were collected, and the enzyme was dialyzed against P-buffer.

\section{Polyacrylamide gel electrophoresis}

The homogeneity of the enzyme preparation was examined by polyacrylamide disc gel electrophoresis (PAGE). Electrophoresis was done in $7.5 \%$ polyacrylamide gel in Tris-glycine buffer $(\mathrm{pH} 8.6)$ with a current of $2.0 \mathrm{~mA}$ per tube for $1.2 \mathrm{~h}$ at $0^{\circ} \mathrm{C}$ by the method of Hames ${ }^{8)}$. Gels were stained for protein with Coomassie brilliant blue G-250.

\section{Determination of molecular weight}

The molecular weight of the purified enzyme was estimated by gel filtration using a Superose 12 (Pharmacia) according to the method by Andrews ${ }^{1)}$. The column $(1.0 \times 30 \mathrm{~cm})$ was equilibrated with P-buffer containing $0.1 \mathrm{M}$ sodium chloride. The purified enzyme was eluted in 0.25 $\mathrm{ml}$ fractions at a flow rate of $15 \mathrm{ml} / \mathrm{h} . \quad \beta$-Amylase (MW 200,000), alchohol dehydrogenase (MW 150,000), albumin; bovine serum (MW 66,000), carbonic anhydrase (MW 29,000) and cytochrome $c$ (MW 12,400) were used as marker proteins.
The molecular weight of the purified enzyme was determined by SDS-polyacrylamide gel electrophoresis as described by Weber and Osborn $^{20)}$ using SDS-PAG PLATE (Daiich Pure Chemicals Co. Ltd., Tokyo) with Tris-glycine buffer ( $\mathrm{pH} 8.4$ ) containing $0.1 \%$ SDS. The electrophoresis was performed at $60 \mathrm{~mA}$ for 60 min. The marker proteins used were glutamate dehydrogenase $(53,000)$, transferrin $(76,000), \beta$ galactosidase $(116,000), \quad \alpha_{2}$-macroglobulin $(170,000)$ and myosin $(212,000)$. The proteins were detected by the silver stain method ${ }^{13)}$.

\section{Isoelectric focusing}

Isoelectric focusing ${ }^{18)}$ was performed using AMPHOLINE PAG PLATE ( $\mathrm{pH}$ 3.5-9.5, Pharmacia) gels on an ATTO AE-3230 apparatus. The gels were prefocused at $300 \mathrm{~V}$ for $60 \mathrm{~min}$ and focused at $300 \mathrm{~V}$ for $120 \mathrm{~min}$ at $4^{\circ} \mathrm{C}$. Anode and cathode solutions were $1.0 \mathrm{M} \mathrm{H}_{3} \mathrm{PO}_{4}$ and $1.0 \mathrm{M} \mathrm{NaOH}$, respectively. After electrofocusing, the protein in the gels was stained with silver stain. pI marker proteins with values of 3.5-9.5 were used as references.

\section{Results and Discussion}

\section{Purification of $I C D H$}

The results of the purification are summarized in Table 1 .

In the first column chromatography using DEAE-Sepharose CL-6B, eleven peaks $(A-K)$ of protein were fractionated (Fig. 1). The two fractions of ICDH were detected only when the isocitrate-oxidizing activity was assayed with NADP as a coenzyme in peaks $E$ to $G$. The first fraction eluted (peak E) from the DEAE-Sepharose column, under these experimental conditions, was designated as ICDH-FI, and the second, peak $\mathrm{G}$, was designated as ICDH-FII.

The ICDH-FI and ICDH-FII fractions were pooled and purified further. Successive chromatographies on gel filtration and then FPLC using a Mono $\mathrm{Q}$ column resulted in single sharp peaks 
Table 1. Purification of isocitrate dehydrogenase

\begin{tabular}{|c|c|c|c|c|c|}
\hline Step & $\begin{array}{l}\text { Total protein } \\
(\mathrm{mg})\end{array}$ & $\begin{array}{l}\text { Total } \\
\text { activity } \\
\text { (U) }\end{array}$ & $\begin{array}{l}\text { Specific } \\
\text { activity } \\
(\mathrm{U} / \mathrm{mg})\end{array}$ & $\begin{array}{l}\text { Purification } \\
\text { (fold) }\end{array}$ & $\begin{array}{c}\text { Yield } \\
(\%)\end{array}$ \\
\hline Cell-free extract & 352.2 & 55.8 & 0.16 & 1.0 & 100 \\
\hline $\begin{array}{l}\text { Ammonium sulfate ppt } \\
(40-60 \% \text { saturation })\end{array}$ & 55.0 & 36.5 & 0.66 & 4.1 & 65.4 \\
\hline \multicolumn{6}{|l|}{ DEAE-Sepharose CL-6B } \\
\hline FI & 1.14 & 8.15 & 7.15 & 44.7 & 14.6 \\
\hline FII & 1.38 & 9.14 & 6.62 & 41.4 & 16.4 \\
\hline \multicolumn{6}{|l|}{ Cellulofine GCL-2000-m } \\
\hline FI & 0.33 & 3.45 & 10.45 & 65.3 & 6.2 \\
\hline FII & 0.55 & 2.43 & 4.42 & 27.7 & 4.4 \\
\hline \multicolumn{6}{|l|}{ Mono Q } \\
\hline FI & 0.01 & 0.11 & 11.0 & 68.8 & 0.2 \\
\hline FII & 0.004 & 0.09 & 22.5 & 140.6 & 0.2 \\
\hline
\end{tabular}

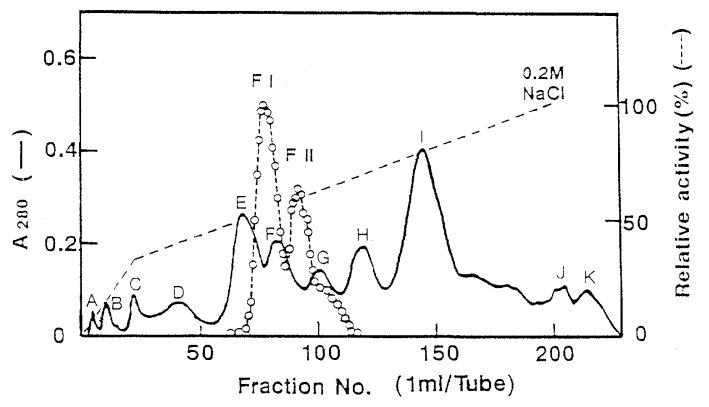

Fig. 1. DEAE-Sepharose CL-6B column chromatography of ICDHs from $N$. europaea.

The experimental details are described in the text. Line : - absorbance at $280 \mathrm{~nm}$

Symbol: $\mathrm{O}, \mathrm{ICDH}$ activity

(Fig. 2).

Homogeneity of the purified enzyme solutions was examined by disc electrophoresis at $\mathrm{pH}$ 8.6. In Fig. 3, a disc electrophoretic pattern of the enzyme is shown, indicating that the preparation is electrophoretically homogeneous. As shown in Table 1, the specific activity of ICDH-FI and ICDH-FII increased 69 -fold (11 units/mg protein) and 140-fold (22.5 units/mg protein).

\section{Molecular weight}

The molecular weights of both native enzymes were estimated at 82,000 by gel filtration. The

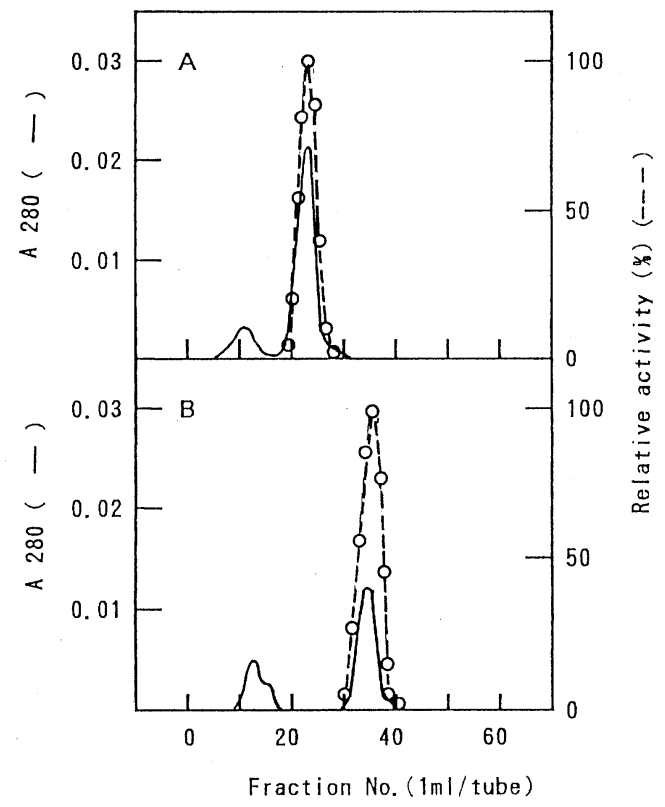

Fig. 2. Mono Q column chromatography of ICDHs from $N$. europaea.

Line : — absorbance at $280 \mathrm{~nm}$

Symbol: $O$, ICDH activity
A : ICDH-FI
B : ICDH-FII

molecular weight of the both denatured enzymes were approximately 82,000 by SDS-PAGE (Fig. 4). This molecular weight is almost same as that 


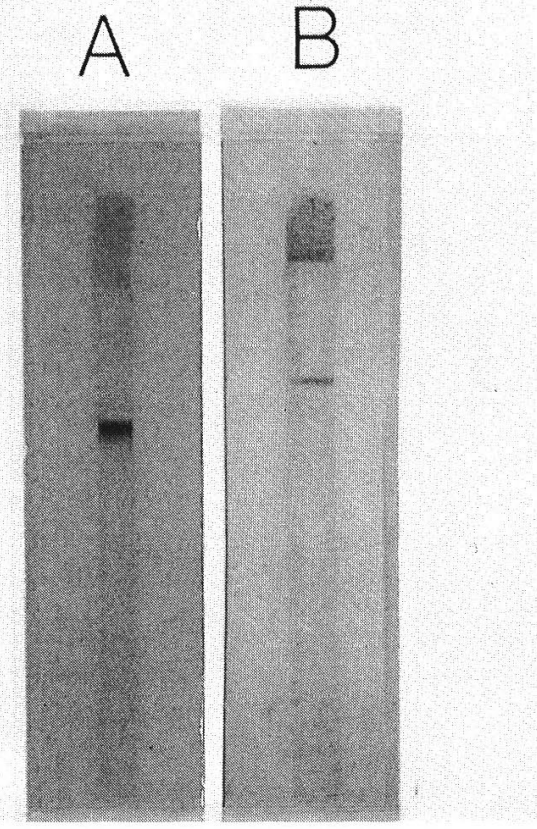

Fig. 3. Polyacrylamide disc gel electerophoresis of the purified ICDHs from $N$. europaea.

Electrophoresis was carried out on $7.5 \%$ gels as described in Materials and Methods.
A : ICDH-FI B : ICDH-FII

reported for enzymes obtained from Escherichia coli $^{15)}$ and Azotobacter venelandi ${ }^{4)}(80,000)$ but were somewhat smaller than that reported for the enzyme obtained from Bacillus stearothermophilus $^{3)}(92,500)$.

\section{Isoelectric point}

From the results of analytical isoelectric focusing of both enzymes on an Ampholine polyacrylamide gel, the isoelectric point $(\mathrm{pI})$ of ICDHFI and ICDH-FII were pH 5.8 and 6.2, respectively. This value is similar to the pI of NADPspecific ICDH from Azotobacter vinelandii $\left.{ }^{4}\right)(\mathrm{pH}$ 6.1). However, the pI of the both enzymes were somewhat different from that of NADP-specific ICDH from Escherichia coli ${ }^{15)}$.

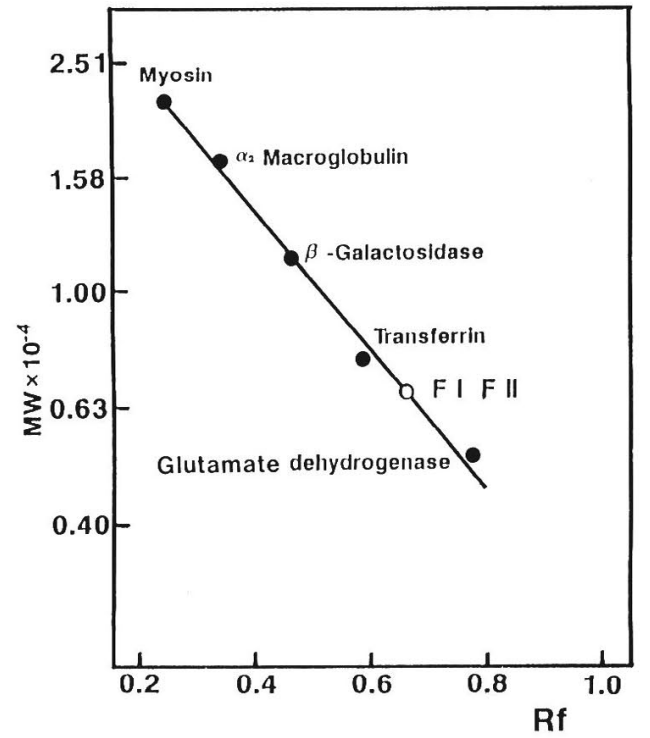

Fig. 4. Estimation of molecular weight of ICDHs by SDS-polyacrylamide gel electrophoresis

Symbols : O, ICDH-FI or ICDH-FII

\section{Effect of $p H$ and temperature on enzyme activity}

The reaction mixture adjusted to an appropriate $\mathrm{pH}$ with Britton-Robinson buffer, was incubated at $45^{\circ} \mathrm{C}$. The optimum $\mathrm{pHs}$ of ICDH-FI and ICDH-FII were found to be 8.5 and 8.0 , respectively (Fig. 5A).

The temperature optima of ICDH-FI and ICDH-FII were both $55^{\circ} \mathrm{C}$ (Fig. 5B).

\section{Effect of temperature on enzyme stability}

To examine the thermal stability of the ICDHFI and ICDH-FII, each enzyme solution was incubated at various temperatures $\left(20-70^{\circ} \mathrm{C}\right)$ for 10 min followed by assay of remaining activity. Both enzymes were stable up to $45^{\circ} \mathrm{C}$ (ICDH-FI) and $50^{\circ} \mathrm{C}$ (ICDH-FII) (Fig. 6).

\section{Substrate and coenzyme specificity}

ICDH activities on D- or DL-isocitrate, cisaconitate, oxalacetate, citrate, 2-oxoglutarate, suc- 

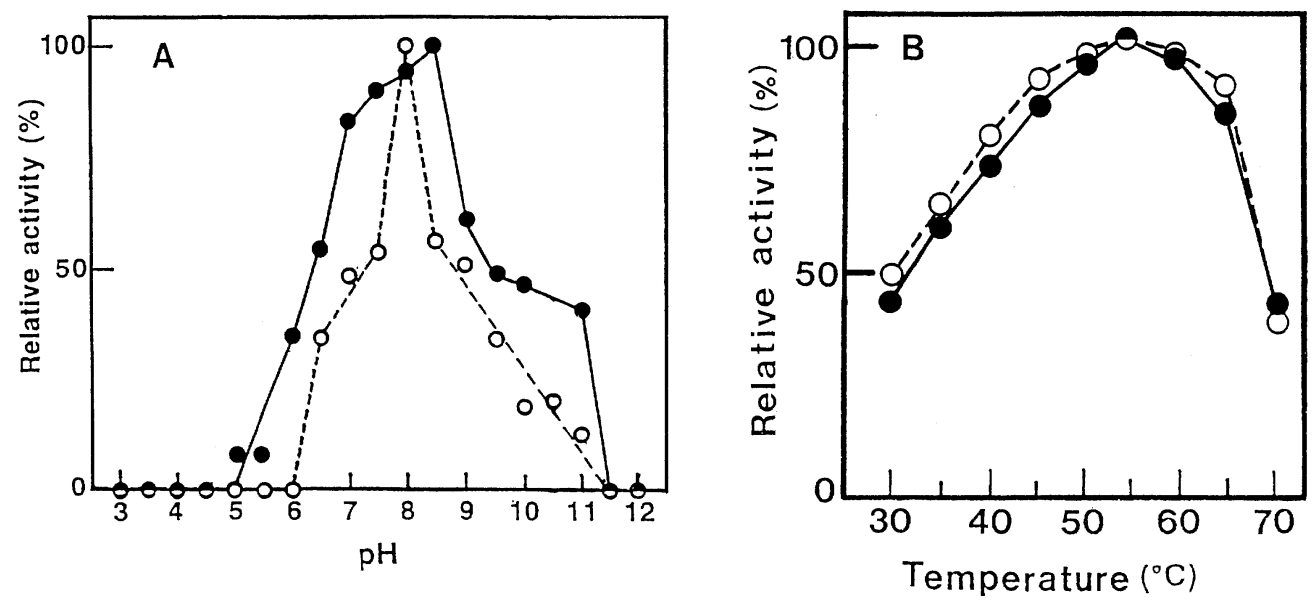

Fig. 5. Effects of $\mathrm{pHs}$ and temperature on the activity of ICDHs.

(A), Optimal pH ; (B), Optimal temprature

Symbols : •, ICDH-FI; O, ICDH-FII

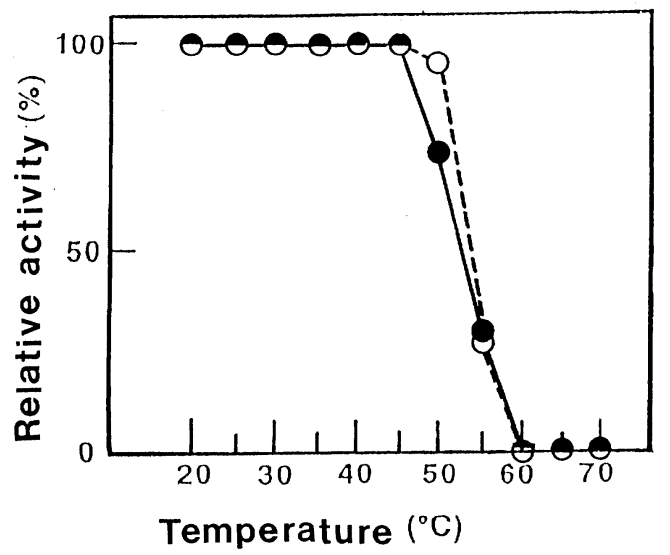

Fig. 6. Effects of temperature on the stability of ICDHs.

Symbols : •, ICDH-FI ; O, ICDH-FII

cinate, fumarate, malate, pyruvate, and phosphoenol pyruvate were compared. Each component was added to the assay mixture to give a final concentration of $1.6 \mathrm{mM}$. ICDH-FI and ICDHFII were active on D- and DL-isocitrate, only with NADP as a coenzyme and showed no activity on the other organic acids. The $K \mathrm{~m}$ value of both ICDH were calculated from a LineweaverBurk plot. The apparent $K \mathrm{~m}$ values of ICDH-FI for D- and DL-isocitrate were $15.0 \mu \mathrm{M}$ and 17.5 $\mu \mathrm{M}$ respectively, and $K \mathrm{~m}$ values of ICDH-FII for D- and DL-isocitrate were $13.0 \mu \mathrm{M}$ and $11.5 \mu \mathrm{M}$ respectively. These $K \mathrm{~m}$ values were similar to that from of the E. coli $(15.6 \mu \mathrm{m})^{15)}$ and $A$. vinelandii ${ }^{4}$. On the other hand, the $K \mathrm{~m}$ values for NADP were $26.8 \mu \mathrm{M}$ for ICDH-FI and 3.8 $\mu \mathrm{M}$ for ICDH-FII.

\section{Action of effectors}

The effects of various metal ions $(1.0 \mathrm{mM})$ and inhibitors $(0.2 \mathrm{mM})$ on ICDH-FI and ICDH-FII activities were examined (data not shown). $\mathrm{Mn}^{2+}$, $\mathrm{Mg}^{2+}$ and $\mathrm{Co}^{2+}$ increased the activity remarkably. On the other hand, some metals such as $\mathrm{Ni}^{2+}, \mathrm{Cu}^{2+}$, $\mathrm{Zn}^{2+}$ and $\mathrm{Hg}^{2+}$ significantly inhibited both enzymes. $p$-Chloromercuribenzoate (PCMB), an oxidant that is specific to $\mathrm{SH}$ terminals, strongly inhibited both enzymes. This is similar to that reported for the NADP-specific ICDH from Bacillus stearothermophilis ${ }^{3}$.

The enzymatic and physicochemical properties of the purified both ICDHs were compared, and are summarized in Table 2. The table show that there are no significant differences between the two enzyme fractions, but the difference in coenzyme specificity were observed. These results suggest 
Table 2. Comparison of properties for both isocitrate dehydrogenases

\begin{tabular}{lcc}
\hline & ICDH-FI & ICDH-FII \\
\hline Optimum pH & 8.5 & 8.0 \\
Optimum temperature $\left({ }^{\circ} \mathrm{C}\right)$ & 55 & \\
Heat stability $\left({ }^{\circ} \mathrm{C}, 10 \mathrm{~min}\right)$ & 45 & 50 \\
Coenzyme & $\mathrm{NADP}^{+}$ & $\mathrm{NADP}^{+}$ \\
pl & 5.8 & 6.2 \\
Molecular weight & 82,000 & 82,000 \\
Km values $(\mu \mathrm{M})$ for : & & \\
$\quad$ D-isocitric acid & 15.0 & 13.0 \\
$\quad$ DL-isocitric acid & 17.5 & 11.5 \\
$\quad$ NADP & 26.8 & 3.8 \\
Effectors $(1 \mathrm{mM})$ & $\mathrm{Mn}^{2+}, \mathrm{Mg}^{2+}$ & $\mathrm{Mn}^{2+}, \mathrm{Mg}^{2+}$ \\
Inhibitors $(0.2 \mathrm{mM})$ & $\mathrm{PCMB}^{2}$ & $\mathrm{PCMB}^{2}$ \\
\hline
\end{tabular}

PCMB ; p-chloromercuribenzoic acid

that both ICDHs exist as a monomer in the native state.

Further investigations on the partial amino acid sequence of ICDH-FI and ICDH-FII will be nessesary to elucidate the difference of both ICDHs from $N$. europaea.

\section{Acknowledgments}

The authors wish to thank Dr. H. Sakurai for his technical assistance. This work was supported in part by Grant-in Aid for Scientific Research from Nihon University, Japan.

\section{References}

1) Andrews, P. 1964. Estimation of the molecular weight of proteins by sephadex gelfiltration. Biochem J. 91, 222-223.

2) Bock, E., H.P. Koops and H. Harms, in "Autotrophic Bacteria”, ed. by H.G. Schlegel and B. Bowien. Springer-Verlag, Berlin, 1989, pp. 81-96.

3) Bradford, M. 1976. A rapid and sensitive method for the quantitation of microgram quantities of protein utilizing the principle of protein-dye binding. Anal. Biochem., 72 , 248-254.

4) Chung, A.E. and J.S. Franzen. 1969. Oxidized Triphosphopyridine nucleotide specific isocitrate dehydrogenase from Azotobacter vinelandii. Isolation and characterization. Biochemistry, 8, 3175-3184.

5) Cook, R.K. and B.D. Sanwal, "Methods in Enzymology”, Vol. XIII, ed. by L. Grossan and K. Moldave. Academic Press, New York, 1969, pp. 42-47.

6) Goldberg, D.M. and G. Ellis, in "Method of Enzymatic Analysis (Third Edition)", Vol. III, ed. by H.U. Bergmeyer. Verlag Chemie, Weinheim 1983, pp. 183-221.

7) Hooper, A.B. 1969. Biochemical basis of obligate autotrophy in Nitrosomonas europaea. J. Bacteriol., 97, 776-779.

8) Hames, B.D. 1981. in "Gel electrophoresis of proteins", ed. by B.D. Hames and D. Rickwood. IRL Press, Oxford - Washington DC, 1981, 5-41.

9) Howard, R.L. and R.R. Becker. 1970. Isolation and some properties of the triphosphopyridine nucleotide isocitrate dehydrogenase from Bacillus stearothermophilus. $J$. Biol. Chem., 245, 3186-3194.

10) Kodama, M., R. Takahashi, T. Kayo and T. Tokuyama. 1989. Properties of partially purified malate dehydrogenases from Nitrosomonas europaea. Abstr. Annu. Meet. Soc. Ferment. Technol. Japan, 181.

11) Layne, E., "Methods in Enzymology" Vol. III, ed. by S.P. Colowick and N.O. Kaplan, Academic Press, New York, 1969, pp. 451-454.

12) Lewis R.F. and P. Pramer. 1958. Isolation of Nitrosomonas in pure culture. J. Bacteriol., 76, 524-528.

13) Oakey, B.R., D.R. Kirsch and N.R. Morris. 1980. A simplified ultrasensitive silver stain for detecting proteins in polyacrylamide gels. Anal. Biochem., 105, 361-363.

14) Ochiai, T., N. Fukunaga and S. Sasaki. 1979. Purification and some properties of two $\mathrm{NADP}^{+}$-specific isolate dehydrogenase from an obligately psychrophilic marine bacterium Vibrio sp., strain ABE-1. J. Biochem., 86, 377-384.

15) Reeves, H.C., G.O. Daumy, C.C. Lin and M. Houston. 1972. NADP ${ }^{+}$-specific isocitrate dehydrogenase of Escherichia coli. I. Purification and characterization Biochem Biophys. Acta, 258, 27-39.

16) Tokuyama, T. and K. Asano. 1978. Oxidation of ammonia with cell fragments of Nitrosomonas europaea. Hakkokogaku (in Japanease), 56, 725-732.

17) Vasquez B. and H.C. Reeves. 1979. NADPspecific isocitrate dehydrogenase of Escherichia coli. IV. purification by chromatography on 
affi-gel blue. Biochem Biophys. Acta, 578, 3140.

18) Vesterbarg, O. and H. Svensson. 1966. Isoelectric fractionation, analysis, and characterization of ampholytes in natural $\mathrm{pH}$ gradients. IV. Further studies on the resolving power in connection with separation of myoglobins. Acta Chem. Scand., 20, 820-834.
19) Watson, S. 1971. Taxonomic considerations of the family Nitrobacteriaceae Buchanan Requests for opinions. Int. J. Syst. Bact., 21, 254-270.

20) Weber, K., J.R. Pringle and M. Osborn, "Methods in Enzymology", Vol. 26, ed. by C. H.W. Hirs and S.N. Timasheff, Academic Press, 1972, pp. 3-27. 